Article

\title{
Chemical Composition, Antimicrobial and Antiparasitic Screening of the Essential Oil from Phania matricarioides (Spreng.) Griseb.
}

\author{
Yamilet I. Gutiérrez ${ }^{1}$, Ramón Scull ${ }^{1}$, Anabel Villa ${ }^{2}$, Prabodh Satyal ${ }^{3}$, Paul Cos ${ }^{4,5}$, \\ Lianet Monzote $5,6, *$ and William N. Setzer $3,5,7, *$ (D) \\ 1 Department of Pharmacy, Institute of Pharmacy and Food, Havana University, Coronela, Lisa, Havana 13600, \\ Cuba; ygutierrez@infomed.sld.cu (Y.I.G.); rscull@ifal.uh.cu (R.S.) \\ 2 Genetic toxicology and antitumor laboratory, Drug Research and Development Center (CIDEM), \\ Havana 10600, Cuba; anabel.villa@cidem.cu \\ 3 Aromatic Plant Research Center, 230 N 1200 E, Suite 100, Lehi, UT 84043, USA; psatyal@aromaticplant.org \\ 4 Laboratory for Microbiology, Parasitology and Hygiene (LMPH), Faculty of Pharmaceutical, Biomedical and \\ Veterinary Sciences, University of Antwerp, 2610 Wilrijk, Belgium; paul.cos@ua.ac.be \\ 5 Research Network Natural Products against Neglected Diseases (ResNet NPND) \\ 6 Parasitology Department, Center of Research, Diagnostic and Reference, Institute of Tropical Medicine \\ "Pedro Kouri", Havana 10400, Cuba \\ 7 Department of Chemistry, University of Alabama in Huntsville, Huntsville, AL 35899, USA \\ * Correspondence: monzote@ipk.sld.cu (L.M.); wsetzer@chemistry.uah.edu or \\ wsetzer@aromaticplant.org (W.N.S.); Tel./Fax: +53-7-255-3612 (L.M.); +1-256-824-6519 (W.N.S.)
}

Academic Editors: Valeria Patricia Sülsen and Albertina Moglioni

Received: 3 April 2019; Accepted: 22 April 2019; Published: 24 April 2019

check for updates

\begin{abstract}
Essential oils (EOs) have gained increasing attention due to their pharmacological effectiveness, and they also constitute some of the most popular natural products. In this study, we present the chemical characterization of the EO from Phania matricarioides and the in vitro activity/selectivity against a wide panel of bacteria, fungi and parasitic protozoa. Forty-five compounds were identified in the studied EO, of which lavandulyl acetate $(40.1 \%)$ and thymyl isobutyrate $(13.9 \%)$ were the major components. The EO did not inhibit bacterial or fungal growth at the maximum concentration tested $(64 \mu \mathrm{g} / \mathrm{mL})$, although it displayed activity on all evaluated protozoa ( $\mathrm{IC}_{50}$ values ranging from 2.2 to $56.6 \mu \mathrm{g} / \mathrm{mL}$ ). In parallel, the EO demonstrated a noteworthy cytotoxic activity against peritoneal macrophages $\left(\mathrm{CC}_{50}\right.$ values of $\left.28.0 \mu \mathrm{g} / \mathrm{mL}\right)$. The most sensitive microorganism was Trypanosoma cruzi, which had a superior activity $\left(\mathrm{IC}_{50}=2.2 \mu \mathrm{g} / \mathrm{mL}\right)$ and selectivity $(\mathrm{SI}=13)$ in respect to other parasitic protozoa and the reference drug $(p<0.05)$. Further in vivo studies are needed to evaluate the potential use of this EO and the main compounds as antitrypanosomal agents. To our knowledge, this is the first report of chemical characterization and antimicrobial assessment of the EO from P. matricarioides.
\end{abstract}

Keywords: Phania matricarioides; essential oil; antimicrobial screening; cytotoxicity; Trypanosoma cruzi

\section{Introduction}

Indiscriminate and irrational use of antimicrobial agents has created an unprecedented challenge for human civilization due to the microbes' development of antimicrobial resistance. Complementary and alternative medicines (CAMs) are used by $60-80 \%$ of developing countries, as they are one of the most prevalent sources of medicine worldwide. In recent years, research on plant-based drugs has increased tremendously, and there is some hope seen in certain medicinal plants that have immense potential to combat bacterial, fungal, protozoal and viral diseases with 
safety. Such plant metabolites include quinones, alkaloids, lectins, polypeptides, flavones, flavonoids, flavonols, coumarins, terpenoids, phenylpropanoids and tannins [1,2]. In particular, other plant-derived natural products, such as essential oils (EOs), have experienced an upsurge in attention due to their efficacious bioactivities [3], and represent one of the most popular natural product classes due to their applications in dermatology, cosmetics and aromatherapy [4]. There have been numerous publications regarding the utility of EOs as antimicrobial, anticancer, anti-inflammatory and antiviral agents. In recent years, numerous papers reporting antimicrobial properties of EOs extracted from higher plants have been published, including antibacterial, antifungal and antiparasitic activities [5].

Recently, we have focused on Phania matricarioides (Spreng.) Griseb. (Figure 1) (Asteraceae or Compositae family), which has been traditionally used for digestive conditions (stomach pain, bad digestion and diarrhea) and dermatological lesions [6,7]. P. matricarioides is included in a very large and widespread family of flowering plants that grow for ornamental purposes [8], but the family also represents a certain economic importance due to the provision of products such as cooking oils, lettuce, sunflower seeds, artichokes, sweetening agents, coffee substitutes and herbal teas [9]. In addition, many species possess medicinal properties, including antioxidant [10], antiparasitic [11], anticancer [12] and hepatoprotective [13]. In particular, the antidiarrheal, analgesic, anti-inflammatory and anti-oxidant effects of extracts have been demonstrated and correlated with some active common phytochemicals such as phenolic compounds, tannins, flavonoids, lactonic compounds, triterpenes or steroids, terpenes and organic acids [6,14,15]. However, as far as we know, the EO from P. matricarioides has not been chemically characterized, and its biological properties have not been scientifically demonstrated.

In this study, taking into account the antimicrobial potential of EOs, we have chemically characterized of the EO from P. matricarioides and screened for potential activity/selectivity against bacteria, fungi and parasitic protozoa of medical relevance.

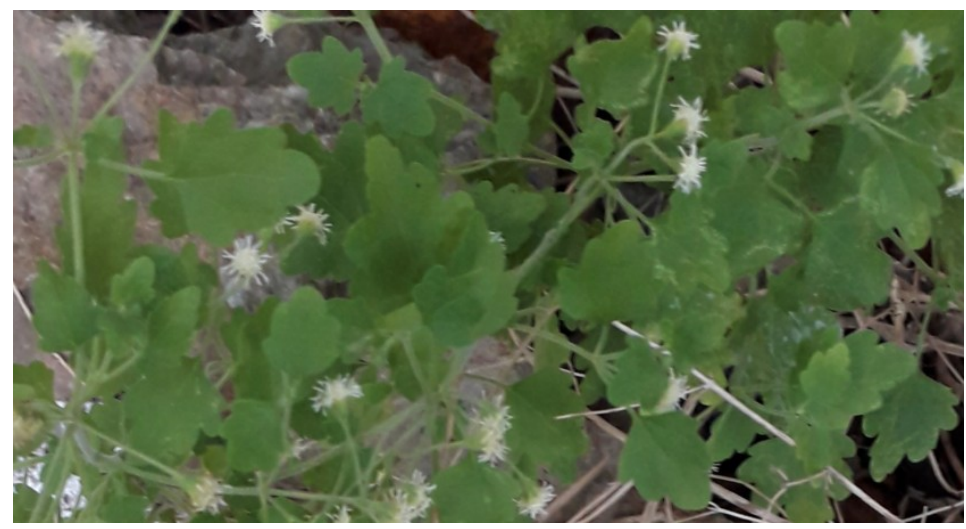

Figure 1. Phania matricarioides in a natural habitat. Picture taken by the authors during collection of the plant (March 2013, Bauta municipality, Artemisa, Cuba).

\section{Results}

The obtained volatile oil from P. matricarioides was colorless and aromatic, and yielded $0.1 \pm 0.002 \%$. The results of the gas chromatography-mass spectrometry (GC/MS) are summarized in Table 1, and show that the chemical composition of the EO was made up of 48 compounds, of which 45 components were identified, representing $98.9 \%$ of the total oil. The predominant components were lavandulyl acetate (40.1\%), followed by thymyl isobutyrate (13.9\%) (Table 1 and Figure 2 ).

The EO did not exhibit bacterial or fungal growth inhibition at the maximum concentration tested $(64 \mu \mathrm{g} / \mathrm{mL})$. However, as demonstrated in Table 2, the EO displayed activity on all evaluated protozoa with varying degrees of inhibition ( $\mathrm{IC}_{50}$ values: $2.2-56.6 \mu \mathrm{g} / \mathrm{mL}$ ). The most sensitive microorganism was Trypanosoma cruzi, which demonstrated a superior susceptibility to the $\mathrm{EO}(p<0.05)$ than the other parasitic protozoa, or the reference drug. 
Table 1. Peak assignment for the gas chromatography-mass spectrometry profile of the essential oil extracted by hydrodistillation from Phania matricarioides collected in Bauta municipality, Artemisa, Cuba.

\begin{tabular}{|c|c|c|}
\hline $\mathrm{RI}^{\mathrm{a}}$ & Compound & Area $(\%)$ \\
\hline 994 & Yomogi alcohol & 0.1 \\
\hline 1099 & Linalool & 0.3 \\
\hline 1154 & (Z)-chrysenthemol & 0.2 \\
\hline 1163 & Lavandulol & 5.5 \\
\hline 1215 & Coahuilensol methyl ether & 0.7 \\
\hline 1217 & 3-isopropylbenzaldehyde & 0.2 \\
\hline 1276 & Chrysanthemyl acetate & 1.4 \\
\hline 1283 & Lavandulyl acetate & 40.1 \\
\hline 1289 & Thymol & 1.2 \\
\hline 1325 & Silphiperfol-5-ene & 0.3 \\
\hline 1332 & $\delta$-elemene & 0.3 \\
\hline 1344 & 7-epi-silphiperfol-5-ene & 1.8 \\
\hline 1349 & Neryl acetate & 0.2 \\
\hline 1357 & Silphiperfol-4,7(14)-diene & 0.4 \\
\hline 1376 & $\alpha$-copaene & 3.2 \\
\hline 1389 & $\beta$-elemene & 0.9 \\
\hline 1411 & Thymohydroquinone dimethyl ether & 1.2 \\
\hline 1415 & Lavandulyl isobutyrate & 0.1 \\
\hline 1420 & $\beta$-caryophyllene & 3.3 \\
\hline 1456 & $\alpha$-humulene & 1.1 \\
\hline 1460 & allo-aromadendrene & 0.3 \\
\hline 1473 & 8,9-dehydrothymyl isobutyrate & 5.9 \\
\hline 1475 & Thymyl isobutyrate & 13.9 \\
\hline 1483 & Neryl isobutyrate & 1.0 \\
\hline 1495 & Bicyclogermacrene & 3.7 \\
\hline 1515 & Cubebol & 0.3 \\
\hline 1518 & $\beta$-guaiene & 0.4 \\
\hline 1536 & Silphiperfol-5-en-3-ol B & 0.2 \\
\hline 1545 & Silphiperfol-5-en-3-one B & 0.1 \\
\hline 1558 & Silphiperfol-5-en-3-ol A & 0.3 \\
\hline 1560 & $(E)$-nerolidol & 0.7 \\
\hline 1565 & Thymyl 2-methylbutanoate & 1.6 \\
\hline 1570 & Neryl 2-methylbutanoate & 1.1 \\
\hline 1576 & Spathulenol & 0.9 \\
\hline 1582 & Caryophyllene oxide & 0.4 \\
\hline 1584 & allo-spathulenol & 1.7 \\
\hline 1588 & $\beta$-copaen- $4 \alpha$-ol & 0.3 \\
\hline 1595 & Fokienol & 0.8 \\
\hline 1604 & Ledol & 0.4 \\
\hline 1618 & Silphiperfol-6-en-5-one & 0.2 \\
\hline 1621 & Unidentified $^{\mathrm{b}}$ & 0.5 \\
\hline 1629 & Unidentified $^{\mathrm{c}}$ & 0.4 \\
\hline 1632 & Caryophylla-4(12),8(13)-dien-5 $\alpha$-ol & 0.5 \\
\hline 1637 & Caryophylla-4(12),8(13)-dien-5 $\beta$-ol & 0.4 \\
\hline 1644 & $\tau$-murrolol & 0.2 \\
\hline 1655 & $\alpha$-cadinol & 0.3 \\
\hline 1667 & 6-methoxythymyl isobutyrate & 0.9 \\
\hline 1726 & Unidentified $^{\mathrm{d}}$ & 0.2 \\
\hline
\end{tabular}

a RI: retention index (determined with respect to a homologous series of $n$ alkanes on a ZB-5 column). ${ }^{\mathrm{b}} \mathrm{MS}$ (EI): 218(24\%), 203(8\%), 175(36\%), 161(17\%), 147(59\%), 133(46\%), 120(53\%), 119(80\%), 107(74\%), 105(100\%), 93(42\%), 91(60\%), 79(37\%), 69(29\%), 55(37\%), 43(36\%), 41(37\%). ${ }^{\mathrm{c}} \mathrm{MS}(\mathrm{EI}): 164(4 \%), 146(69 \%), 135(100 \%), 115(10 \%), 91(16 \%)$, 71(28\%), 43(70\%). ${ }^{\mathrm{d}} \mathrm{MS}(\mathrm{EI}):$ 149(5\%), 135(3\%), 121(5\%), 107(3\%), 93(8\%), 83(100\%), 68(9\%), 55(24\%), 43(5\%). 


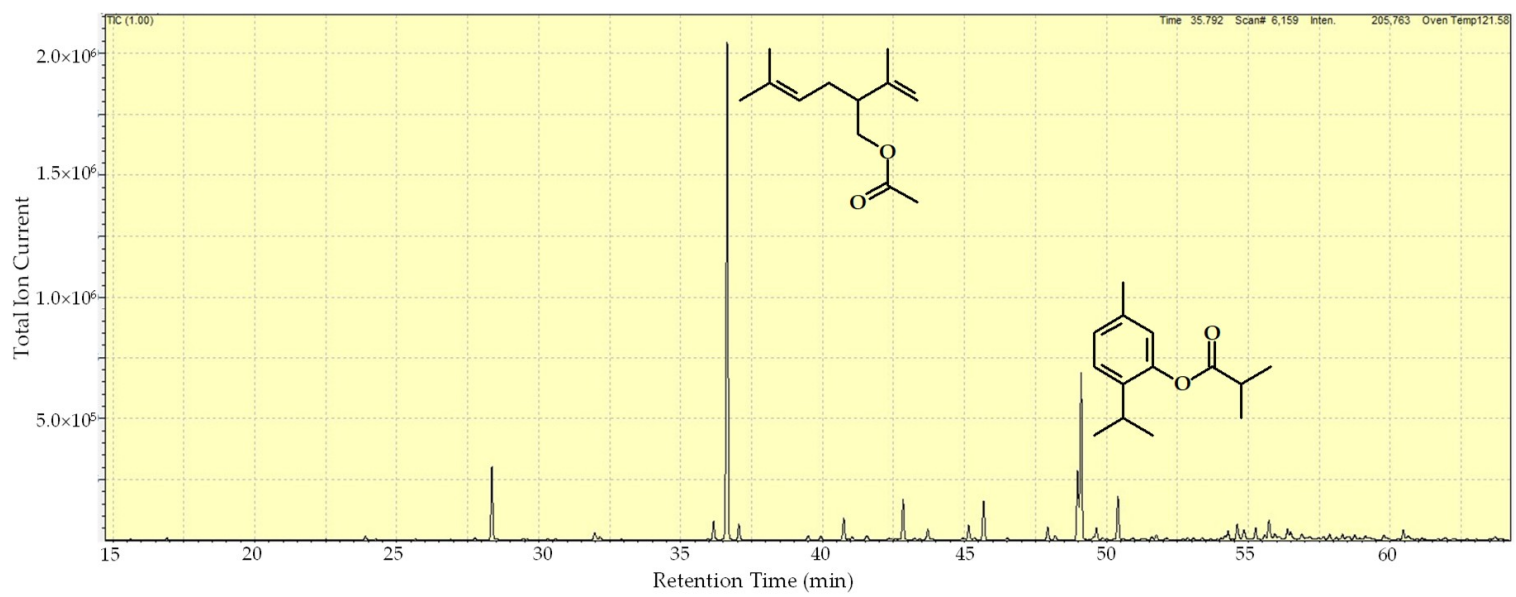

Figure 2. Gas chromatogram and major components of the essential oil extracted by hydrodistillation from P. matricarioides collected in Bauta municipality, Artemisa, Cuba.

In parallel, the EO demonstrated a noteworthy cytotoxic activity against peritoneal macrophages, as shown in Table 2. The most selective parasite was also T. cruzi, with a SI greater than 10.

Table 2. Antiprotozoal activity and cytotoxic effects of essential oil extracted by hydrodistillation from P. matricarioides collected in Bauta municipality, Artemisa, Cuba.

\begin{tabular}{|c|c|c|c|c|c|}
\hline & \multicolumn{5}{|c|}{$\mathrm{IC}_{50}(\mu \mathrm{g} / \mathrm{mL})^{\mathrm{a}}$} \\
\hline & P. falciparum & T. brucei & T. cruzi & L. amazonensis & L. infantum \\
\hline Essential oil & 20.7 & 8.0 & 2.2 & 56.6 & 7.5 \\
\hline \multirow[t]{2}{*}{ Reference drug ${ }^{c}$} & 0.02 & 0.04 & 3.2 & 0.02 & 3.7 \\
\hline & \multicolumn{5}{|c|}{$\begin{array}{l}\mathrm{CC}_{50}(\mu \mathrm{g} / \mathrm{mL})^{b} \\
\text { Peritoneal Macrophage }\end{array}$} \\
\hline Essential oil & \multicolumn{5}{|c|}{28.0} \\
\hline \multirow[t]{3}{*}{ Reference drug $^{c}$} & \multicolumn{5}{|c|}{5.8} \\
\hline & \multicolumn{5}{|c|}{ Selectivity Index d } \\
\hline & P. falciparum & T. brucei & T. cruzi & L. amazonensis & L. infantum \\
\hline Essential oil & 1 & 4 & 13 & 0 & 4 \\
\hline Reference drug $^{c}$ & 290 & 145 & 2 & 290 & 2 \\
\hline
\end{tabular}

${ }^{\mathrm{a}} \mathrm{IC}_{50}$ : Median inhibitory concentration. ${ }^{\mathrm{b}} \mathrm{CC}_{50}$ : Median cytotoxic concentration. ${ }^{\mathrm{c}}$ Reference drugs: Chloroquine for Plasmodium falciparum, suramine for Trypanosoma brucei, benznidazol for Trypanosoma cruzi, miltefosine for Leishmania infantum and amphotericin B for Leishmania amazonensis and peritoneal macrophage. ${ }^{\mathrm{d}}$ Selectivity index (SI): $\mathrm{CC}_{50 /} \mathrm{IC}_{50}$.

\section{Discussion}

Innovative approaches for effective proof-of-concept research and the development of new types of plant-derived products effective against recently emerging problems related to human microbial diseases are needed. In this regard, research on antimicrobial agents from natural sources has grown in importance in order to discover novel, effective and less expensive drugs, and to combat microbial resistance. Consequently, in our continuing search for valuable and promising natural products from Cuban medicinal plants against infectious diseases, this study was carried out to analyze the chemical composition of the EO from P. matricarioides, and was extended to investigate the antimicrobial activity of this product against a wide panel of microorganisms.

Cabrera et al. reported that the yield of EO from fresh aerial parts of $P$. matricarioides range between $0.06 \%$ and $0.41 \%$ under different conditions of treatment of the plant material (fresh plant material, drying in the shade and drying in a stove) [6]. Thus, in the present investigation, the yield 
fell into the referred range. Although the oil yield was not high, it played an important role in the biological activities presented by the plant, justifying in some way its traditional dermatological and digestive uses.

In the studied EO, a high percentage of compounds, around 99\%, were identified. The chemical composition profile included a broad spectrum of components, such as monoterpene derivatives. The main compound of EO was lavandulyl acetate (acetate ester of lavandulol, a known component of lavender oil), which has been also identified in EOs from Heracleum sprengelianum Wight \& Arn. [16], Lavandula angustifolia Mill. [17] and Pycnocycla nodflora Decne. ex Boiss. [18]. The biological potentiality of this compound was demonstrated through the larvicidal activity against three important mosquito vectors [16]. Another major compound was thymyl isobutyrate, a phenolic monoterpene derivative (ester of thymol) with recognized antimicrobial activity [19].

EOs improve the shelf-life of packaged products and control microbial growth [20], which has provided evidence that EOs are natural antimicrobials isolated from plants [21]. There have been no previous studies on the antimicrobial activity of $P$. matricarioides, and our results showed that the tested bacteria and fungi strains were not sensitive to the studied oil at the concentrations tested.

There have been several studies reported in the literature, supporting the suggestion that certain EOs from various plant species can demonstrate antiparasitic activity [22-25]. As has been demonstrated in the present study, the EO from P. matricarioides inhibited the growth of all tested parasites, with $\mathrm{IC}_{50}$ ranging from 2 to $57 \mu \mathrm{g} / \mathrm{mL}$. In comparison with reference drugs, the studied EO showed higher $\mathrm{IC}_{50}$ values with statistical differences $(p<0.05)$, except in the case of T. cruzi, which displayed higher sensitivity $(p<0.05)$ to the EO than to benznidazole. Other Cuban EOs, have also demonstrated a wide spectrum of antiprotozoal activity, including Chenopodium ambrosioides L. [22] and Piper aduncum L. [23]. Nevertheless, as biological properties of the main identified compounds in the studied EO are still scarce, further studies of pure compounds, other components and/or synergistic effects remain to be analyzed to explain the observed activities.

Meanwhile, cytotoxic effects on macrophages from mice were determined and used to calculate the selectivity index (SI). The EO showed low SI values in general, except in the case of T. cruzi. It is known that one of most important criteria to select "hits" during in vitro screening is to demonstrate a SI superior to 10 [26], which was only accomplished by the T. cruzi parasite $(S I=13)$.

T. cruzi, the causal agent of Chagas disease, is a complex zoonosis transmitted by more than 100 species of triatomine insects (Hemiptera: Reduviidae: Triatominae) and sustained by more than 70 genera of mammalian hosts, including humans [27]. Infection is endemic from Northern Mexico to Argentina, and is considered the parasitic infection with the greatest socioeconomic burden in Latin America, although human migrations have earned it global importance [28,29]. Clinical development of the disease has two successive phases: acute phase (typically asymptomatic or with variable symptoms that may last four to eight weeks) and chronic phase (presented in the majority of patients as chronic infection, which can develop irreversible lesions of the heart, esophagus or colon, ultimately leading to death of the patient) $[27,30]$. Although many vector control programs have been implemented, T. cruzi has not been eradicated, and the development of an effective human vaccine against Chagas disease has been slow [31]. Currently, the only two anti-trypanosomal drugs available for Chagas disease — benznidazole and nifurtimox — are far from ideal. Both require prolonged treatment, display a wide range of side effects and, although being effective in the acute phase, have a limited efficacy in the chronic stage $[32,33]$. In this sense, one approach to the development process of new antitrypanosomal drugs has been the search of natural products [34]. In particular, several EOs from plants, such as Alpinia speciosa K. Schum [25], Lippia alba N.E.Br. ex Britton \& P. Wilson [35], Piper tuberculatum Jacq. [24] and Protium ovatum Engl. [36], have demonstrated efficacy against T. cruzi.

Against the other tested protozoal parasites, higher $\mathrm{IC}_{50}$ values were obtained $(7.5-56.6 \mu \mathrm{g} / \mathrm{mL})$. However, in this case it should be taken into account that EOs are mixtures of different components, and the main antiprotozoal principle could be in a lower concentration. As a consequence for these parasites, lower SI values $(\leq 4)$ were also observed, which limit the potential application of the studied 
EO by a systemic administration route, although the application by a topical route could be feasible as well as the use of carriers such as nanoparticles [37]. In particular, the current search for new alternatives against P. falciparum, L. amazonensis and L. infantum (causal agents of malaria, cutaneous and visceral leishmaniasis, respectively) constitute an interesting approach to target multiparasite infections with the same drugs in the control programs of endemic countries [38].

\section{Materials and Methods}

\subsection{Plant Material}

The aerial parts of P. matricarioides were collected early in the morning in March 2013 in Bauta municipality $\left(22^{\circ} 59^{\prime} 31^{\prime \prime} \mathrm{N}, 82^{\circ} 32^{\prime} 57^{\prime \prime} \mathrm{W}, 10 \mathrm{~m}\right.$ asl), Artemisa province, Cuba. A plant specimen was authenticated by Professor Jorge Gutiérrez Amaro and deposited in the Herbarium of National Botany Garden of Havana, Cuba, under the voucher number HFC 88669. Vegetable material was washed with abundant common water and manually crushed.

\subsection{Essential Oil Extraction and Chemical Characterization}

To obtain the EO from P. matricarioides, fresh vegetal material was hydrodistilled using a Clevenger type apparatus for $5 \mathrm{~h}$. For the biological assays, the EO was dissolved in dimethyl sulfoxide (DMSO) at $20 \mathrm{mg} / \mathrm{mL}$.

Chemical characterization of the EO was carried out by gas chromatography coupled with a mass spectrometric detector (GC-MS) using Shimadzu GCMS-QP2010 Ultra (Shimadzu Scientific Instruments, Columbia, MD, USA) equipment, which was operated in the electron impact (EI) mode (electron energy $=70 \mathrm{eV}$ ), with a scan range $=40-400$ atomic mass units, scan rate $=3.0 \mathrm{scans} / \mathrm{s}$ and GC-MS solution software. The GC column was a ZB-5-fused silica capillary column with a (5\% phenyl)-polymethylsiloxane stationary phase and a film thickness of $0.25 \mu \mathrm{m}$, a length of $30 \mathrm{~m}$ and an internal diameter of $0.25 \mathrm{~mm}$ (Phenomenex, Torrance, CA, USA). The carrier gas was helium with a column head pressure of $552 \mathrm{kPa}$ and a flow rate of $1.37 \mathrm{~mL} / \mathrm{min}$. The injector temperature was $250{ }^{\circ} \mathrm{C}$ and the ion source temperature was $200^{\circ} \mathrm{C}$. The GC oven temperature program was programmed for a $50{ }^{\circ} \mathrm{C}$ initial temperature, with temperature increased at a rate of $2{ }^{\circ} \mathrm{C} / \mathrm{min}$ to $260{ }^{\circ} \mathrm{C}$. A $5 \%$ w $/ v$ solution of the sample in $\mathrm{CH}_{2} \mathrm{Cl}_{2}$ was prepared, and $0.1 \mu \mathrm{L}$ was injected with a splitting mode (30:1). Identification of the oil components was based on their retention indices (RI) as determined in reference to a homologous series of $n$ alkanes using the method of Kovats [39], and by comparison of their mass spectral fragmentation patterns with those reported in the literature [40], and stored in our in-house Sat-Set library [41].

\subsection{Microorganisms}

An integrated panel of microbial agents in a 96-well plate was adopted from Cos et al. [42], including Gram-negative Escherichia coli (ATCC8739), Gram-positive Staphylococcus aureus (ATCC6538), yeast Candida albicans (B59630), and protozoa Plasmodium falciparum (Ghana), Trypanosoma brucei brucei (Squib-427), T. cruzi (Tulahuen CL2), L. infantum (MHOM/MA(BE)/67) and Leishmania amazonensis (MHOM/77BR/LTB0016).

\subsection{Cell Culture}

Cytotoxicity was tested against peritoneal macrophage from BALB/c mice (PMM) obtained by peritoneal washing in RPMI medium (Sigma, St. Louis, MO, USA) and antibiotics (100 $\mu \mathrm{g}$ of streptomycin/mL, $100 \mathrm{U}$ of penicillin/mL; Sigma, St. Louis, MO, USA) at the moment of use.

\subsection{Antibacterial and Antifungal Assays}

E. coli and S. aureus were cultured in Mueller Hinton broth (MHB; Sigma-Aldrich, St. Louis, MO, USA) medium; while C. albicans was cultured in RPMI medium. In all cases, $5 \times 10^{3} \mathrm{CFU} /$ well 
was added with different EO concentrations ranging from 0.25 to $64 \mu \mathrm{g} / \mathrm{mL}$. After $17 \mathrm{~h}$ of incubation at $37^{\circ} \mathrm{C}$, bacterial or fungal viability was determined fluorimetrically by the addition of resazurin (Sigma-Aldrich, St. Louis, MO, USA) for $30 \mathrm{~min}$ at $37^{\circ} \mathrm{C}$ to bacteria cultures, or $4 \mathrm{~h}$ at $37{ }^{\circ} \mathrm{C}$ to fungi [43]. Finally, fluorescence was measured using a Tecan GENios Multifunction Fluorimeter (Tecan Group, Maennedorf, Switzerland) at $530 \mathrm{~nm}$ excitation and emission of $590 \mathrm{~nm}$. At the same time, reference drugs were tested, including chloramphenicol (Sigma-Aldrich, Bornem, Belgium) for E. coli, erythromycin (Sigma-Aldrich, Bornem, Belgium) for S. aureus and miconazole (Janssen Pharmaceuticals, Beerse, Belgium) for C. albicans.

\subsection{Antiprotozoal Assays}

Antiplasmodial activity was determined with parasites cultured in human erythrocytes A+ in RPMI-1640 culture medium, supplemented with $0.5 \%(w / v)$ Albumax at $37^{\circ} \mathrm{C}$ under an atmosphere of $3 \% \mathrm{O}_{2}, 4 \% \mathrm{CO}_{2}$ and $93 \% \mathrm{~N}_{2}$ [44]. Suspensions of infected human red blood cells ( $1 \%$ parasitemia, $2 \%$ hematocrit) were added to each well with the same test concentrations of EO. The plate was incubated for $72 \mathrm{~h}$ under the same conditions, and then the plate was frozen at $-20{ }^{\circ} \mathrm{C}$. Parasite multiplication was measured after mixing $20 \mu \mathrm{L}$ of the hemolyzed parasite suspension with $100 \mu \mathrm{L}$ of Malstat (Flow Incorporated, USA) reagent in a new plate, and incubated for $15 \mathrm{~min}$ at room temperature. After that, $20 \mu \mathrm{L}$ of nitro blue tetrazolium chloride (NBT; Sigma Aldrich, St. Louis, MO, USA) at $2 \mathrm{mg} / \mathrm{mL} /$ phenazine ethosulfate (PES; Sigma Aldrich, St. Louis, MO, USA) at $0.1 \mathrm{mg} / \mathrm{mL}$ solution was added. The plate was incubated again for $2 \mathrm{~h}$ at room temperature in the dark and the absorbance was read at $655 \mathrm{~nm}$ in a Biorad 3550-UV microplate reader. Chloroquine, donated by the Special Programme for Research and Training in Tropical Diseases from the World Health Organization (WHO-TDR), was also included as a reference drug.

Antitrypanosomal activity was performed using trypomastigotes of T. brucei, cultured in Hirumi-9 medium supplemented with $10 \%$ inactivated fetal calf serum (FCSi) at $37{ }^{\circ} \mathrm{C}$ and $5 \% \mathrm{CO}_{2}$ [45]. Assays were performed by adding $1.5 \times 10^{4}$ trypomastigotes/well to the $\mathrm{EO}$ at the mentioned concentrations. After $72 \mathrm{~h}$ of incubation at the same conditions, parasite growth was assessed fluorimetrically by adding resazurin for $24 \mathrm{~h}$ at $37^{\circ} \mathrm{C}$. In parallel, activity on amastigotes of T. cruzi was also evaluated. In this case, the EO at tested concentrations was added to $4 \times 10^{4}$ amastigotes in $4 \times 10^{3}$ MRC-5 cells maintained in minimal essential medium (MEM; Life Technologies, USA) supplemented with $20 \mathrm{mM}$ L-glutamine, $16.5 \mathrm{mM}$ sodium bicarbonate and 5\% of FCSi. After an additional incubation for seven days at the previous conditions, parasite growth was assessed by adding the $\beta$-galactosidase substrate chlorophenol red $\beta$-D-galactopyranoside (Sigma Aldrich, St. Louis, MO, USA) and then incubating for $4 \mathrm{~h}$ at $37^{\circ} \mathrm{C}$. The absorbance was then read at $540 \mathrm{~nm}$ [46]. As reference drugs, suramine for T. brucei and benznidazol for T. cruzi were used, which were kindly donated by WHO-TDR.

Antileishmanial activities against the intracellular amastigote form of L. infantum and L. amazonensis were performed. For L. infantum, $3 \times 10^{4} \mathrm{PMM}$ were infected with amastigotes obtained from an infected hamster at a density of 15 parasites per cell, and the plate was incubated for $48 \mathrm{~h}$ at $37^{\circ} \mathrm{C}$ and $5 \% \mathrm{CO}_{2}$. Pre-diluted concentrations of $\mathrm{EO}$ were added and the plates were then incubated under the same conditions over a 120 -h period. In the experiment with L. amazonensis, PMM were plated at $10^{6} / \mathrm{mL}$ in a 24 -well Lab-Tek (Costar, USA) and incubated at $37^{\circ} \mathrm{C}$ and $5 \% \mathrm{CO}_{2}$ for $2 \mathrm{~h}$. Non-adherent cells were removed and stationary-phase promastigotes were added at a 4:1 parasite/macrophage ratio for $4 \mathrm{~h}$. Cells were washed to remove free parasites, EO was added, four serial dilutions were carried out to test from 12.5 to $100 \mu \mathrm{g} / \mathrm{mL}$ and the plates were further incubated at same conditions for $48 \mathrm{~h}$ [47]. In both cases, after the incubation period with the products, the supernatant was discarded and cells were fixed with methanol, stained with $10 \%$ Giemsa and microscopically examined (Motic, Japan) under immersion oil. The total parasite burden was determined according to the number of infected macrophages and the number of amastigotes inside the macrophages. Miltefosine (donated by WHO-TDR) and amphotericin B (Imefa, La Habana, Cuba) were used as reference drugs, respectively. 


\subsection{Cytotoxicity Assay}

To assess the cytotoxic effects of the EO, isolated PMM were seeded at $3 \times 10^{5}$ cells $/ \mathrm{mL}$ and incubated at $37^{\circ} \mathrm{C}$ and $5 \% \mathrm{CO}_{2}$ [48]. After $2 \mathrm{~h}$, the medium was removed and $98 \mu \mathrm{L}$ of fresh medium with $10 \%$ FCSi and antibiotics were added, with an additional $48 \mu \mathrm{L}$ in the first wells and $2 \mu \mathrm{L}$ of pre-diluted EO, ranging from 12.5 to $200 \mu \mathrm{g} / \mathrm{mL}$. The plate was incubated at same conditions for $48 \mathrm{~h}$, and viability was measured with $15 \mu \mathrm{L}$ of 3-[4,5-dimethylthiazol-2-yl]-2,5-diphenyltetrazolium bromide (MTT; SIGMA, St. Louis, MO, USA) solutions. After $4 \mathrm{~h}$, formazan crystals were dissolved with $100 \mu \mathrm{L}$ of DMSO and the optical density was measured at $560 \mathrm{~nm}$ and at $630 \mathrm{~nm}$ as a reference wavelength using a spectrophotometer (Molecular Devices, Silicon Valley, California, USA).

\subsection{Statistical Analysis}

In each case, percentage growth inhibition for each concentration of EO was calculated compared to the untreated controls. The median inhibitory concentration $\left(\mathrm{IC}_{50}\right)$ for antibacterial, antifungal and antiprotozoal assay were determined, while median cytotoxic concentrations $\left(\mathrm{CC}_{50}\right)$ were obtained in the cytotoxicity experiment. In each case, the values were calculated from lineal dose-response curves, and results are expressed as the means of three experiments. To compare the $\mathrm{IC}_{50}$ and $\mathrm{CC}_{50}$ values between $\mathrm{EO}$ and reference drugs, statistical differences were determined using Mann-Whitney with Statistica for Windows program (Release 4.5, StatSoft, Inc., Tulsa, OK, USA, 1993), considering statistical differences as $p<0.05$. Finally, the selectivity index (SI) was calculated for each evaluated product, which was determined by $\mathrm{CC}_{50} / \mathrm{IC}_{50}$.

\section{Conclusions}

To our knowledge this work is the first investigation related to the EO from P. matricarioides, and confirms the importance of chemical, biological and cytotoxicity assessments of EOs. The results demonstrate the wide spectrum of antiparasitic activities, in particular against $T$. cruzi, with a potential margin of safety based on the high SI obtained from comparison with mammalian cells. Further in vivo studies are needed to evaluate the potential use of this EO and its main compounds as antitrypanosomal agents.

Author Contributions: Conceptualization, Y.G. and L.M.; methodology, Y.G., R.S., A.V., P.S., W.N.S., L.M. and P.C.; writing—original draft preparation, L.M.; writing—review and editing, Y.G., P.C. and W.N.S.; project administration, Y.G.

Funding: This research received no external funding.

Acknowledgments: L.M., P.C. and W.N.S. carried out this work as part of the activities of the Research Network Natural Products against Neglected Diseases (ResNetNPND, http://www.resnetnpnd.org/Start/). P.S. and W.N.S. contributed to this project as part of the activities of the Aromatic Plant Research Center (APRC, https://aromaticplant.org/).

Conflicts of Interest: The authors declare no conflict of interest.

\section{Abbreviations}

CAMs: complementary and alternative medicines; $\mathrm{CC}_{50}$ : median cytotoxic concentration; DMSO: dimethyl sulfoxide; EOs: essential oils; FCSi: inactivated fetal calf serum; $\mathrm{IC}_{50}$ : median inhibitory concentration; MEM: minimal essential medium; MHB: Mueller Hinton Broth medium; MTT: 3-[4,5-dimethylthiazol-2-yl]-2,5-diphenyltetrazolium bromide; NBT: nitro blue tetrazolium chloride; PES: phenazine ethosulfate; PMM: peritoneal macrophage from BALB/c mice; RI: retention index; SI: selectivity index; WHO-TDR: Special Programme for Research and Training in Tropical Diseases from the World Health Organization. 


\section{References}

1. Chandra, H.; Bishnoi, P.; Yadav, A.; Patni, B.; Mishra, A.P.; Nautiyal, A.R. Antimicrobial resistance and the alternative resources with special emphasis on plant-based antimicrobials - A review. Plants 2017, 6, 16. [CrossRef]

2. Crofts, T.S.; Gasparrini, A.J.; Dantas, G. Next-generation approaches to understand and combat the antibiotic resistome. Nat. Rev. Microbiol. 2017, 15, 422-434. [CrossRef]

3. Aziz, Z.A.A.; Ahmad, A.; Setapar, S.H.M.; Karakucuk, A.; Azim, M.M.; Lokhat, D.; Rafatullah, M.; Ganash, M.; Kamal, M.A.; Ashraf, G.M. Essential oils: Extraction techniques, pharmaceutical and therapeutic potential-A review. Curr. Drug Metab. 2018, 19, 1100-1110. [CrossRef] [PubMed]

4. Orchard, A.; Vuuren, S. Van Commercial essential oils as potential antimicrobials to treat skin diseases. Evidence-Based Complement. Altern. Med. 2017, 2017, 4517971. [CrossRef]

5. Chouhan, S.; Sharma, K.; Guleria, S. Antimicrobial activity of some essential oils — Present status and future perspectives. Medicines 2017, 4, 58. [CrossRef] [PubMed]

6. Cabrera Suárez, H.R.; Morón Rodríguez, C.F.J.; Victoria Amador, M.d.C.; García Hernández, A.I.; Acosta de la Luz, C.L. Composición fitoquímica de partes aéreas frescas de Phania matricarioides. Rev. Cuba. Plantas Med. 2012, 17, 268-278.

7. García Hernández, A.I.; Victoria Amador, M.d.C.; Morón Rodríguez, C.F.; López Barreiro, M.; Boucourt Rodríguez, E.; Martínez Guerra, M.J.; Morejón Rodríguez, Z. Disminución de tránsito intestinal y ausencia de toxicología aguda preclínicas de la decocción de partes aéreas frescas de Phania matricarioides (Spreng.) Griseb. Rev. Cuba. Plantas Med. 2013, 18, 71-83.

8. Jeffrey, C. Compositae: Introduction with key to tribes. In Families and Genera of Vascular Plants, vol. VIII, Flowering Plants, Eudicots, Asterales; Kadereit, J.W., Jeffrey, C., Eds.; Springer: Berlin, Germany, 2007; pp. 61-87.

9. Singh, R.; Singh, G.; Tiwari, A.K.; Patel, S.; Agrawal, R. Diversity of host plants of aphids (Homoptera: Aphididae) infesting Asteraceae in India. Int. J. Zool. 2015, 1, 137-167.

10. Tania, P.M.; Del Castilo, B.D.; Serrão, P.C.D.; Lobato, R.A.B.; Da Silva, R.R.; Da Silva, R.E.; De Silva de A, S.S.M. The effect antioxidant aqueous crude extract in Acmella ciliata (Kunth.) (Asteraceae). J. Chem. Pharm. Res. 2016, 8, 417-423.

11. Panda, S.K.; Luyten, W. Antiparasitic activity in Asteraceae with special attention to ethnobotanical use by the tribes of Odisha, India. Parasite 2018, 25, 10. [CrossRef]

12. Hiradeve, S.M.; Rangari, V.D. A review on pharmacology and toxicology of Elephantopus scaber Linn. Nat. Prod. Res. 2014, 28, 819-830. [CrossRef] [PubMed]

13. Pang, Y.; Wang, D.; Fan, Z.; Chen, X.; Yu, F.; Hu, X.; Wang, K.; Yuan, L. Blumea balsamifera- A phytochemical and pharmacological review. Molecules 2014, 19, 9453-9477. [CrossRef] [PubMed]

14. García Hernández, A.I.; Victoria Amador, M.d.C.; Morón Rodríguez, F.; Cabrera Suárez, H.; Frías Vázquez, A.I.; López Barreiro, M.; Boucourt Rodríguez, E.; Morejón Rodríguez, Z.; Martínez Guerra, M.J. Validación preclínica de la actividad analgésica y antiinflamatoria de la decocción de partes aéreas frescas de Phania matricarioides (Spreng.) Griseb. Rev. Cuba. Plantas Med. 2012, 17, 380-392.

15. Gutiérrez, Y.I.; Monzote, L.; Rodríguez, K.M.; Bello, A.; Setzer, W.N. Comparative pharmacognosy, chemical profile and antioxidant activity of extracts from Phania matricarioides (Spreng.) Griseb. collected from different localities in Cuba. Plants 2018, 7, 110. [CrossRef] [PubMed]

16. Govindarajan, M.; Benelli, G. Ecotoxicology and environmental safety eco-friendly larvicides from Indian plants: Effectiveness of lavandulyl acetate and bicyclogermacrene on malaria, dengue and Japanese encephalitis mosquito vectors. Ecotoxicol. Environ. Saf. 2016, 133, 395-402. [CrossRef] [PubMed]

17. Robu, S.; Aprotosoaie, A.C.; Spac, A.; Cioancă, O.; Hăncianu, M.; Stănescu, U. [Studies regarding chemical composition of lavender volatile oils]. Rev. Med. Chir. Soc. Med. Nat. Iasi 2011, 115, 584-589. [PubMed]

18. Nasr, M.; Asgarpanah, J. Volatile constituents of the seeds and fruit of Pycnocycla nodiflora. Nat. Prod. Commun. 2014, 9, 1781-1782. [CrossRef]

19. Gupta, V.K.; Fatima, A.; Faridi, U.; Negi, A.S.; Shanker, K.; Kumar, J.K.; Rahuja, N.; Luqman, S.; Sisodia, B.S.; Saikia, D.; et al. Antimicrobial potential of Glycyrrhiza glabra roots. J. Ethnopharmacol. 2008, 116, 377-380. [CrossRef]

20. Vergis, J.; Gokulakrishnan, P.; Agarwal, R.K.; Kumar, A. Essential oils as natural food antimicrobial agents: A review. Crit. Rev. Food Sci. Nutr. 2015, 55, 1320-1323. [CrossRef] 
21. Rao, J.; Chen, B.; McClements, D.J. Improving the efficacy of essential oils as antimicrobials in foods: Mechanisms of action. Annu. Rev. Food Sci. Technol. 2019, 10, 365-387. [CrossRef]

22. Monzote, L.; García, M.; Pastor, J.; Gil, L.; Scull, R.; Maes, L.; Cos, P.; Gille, L. Essential oil from Chenopodium ambrosioides and main components: Activity against Leishmania, their mitochondria and other microorganisms. Exp. Parasitol. 2014, 136, 20-26. [CrossRef] [PubMed]

23. Monzote, L.; Scull, R.; Cos, P.; Setzer, W.N. Essential oil from Piper aduncum: Chemical analysis, antimicrobial assessment, and literature review. Medicines 2017, 4, 49. [CrossRef] [PubMed]

24. Dos Santos Sales, V.; Monteiro, Á.B.; de Araújo Delmondes, G.; do Nascimento, E.P.; Nóbrega de Figuêiredo, F.R.S.D.; de Souza Rodrigues, C.K.; de Lacerda, J.F.E.; Fernandes, C.N.; de Oliveira Barbosa, M.; Brasil, A.X.; Tintino, S.R.; et al. Antiparasitic activity and essential oil chemical analysis of the Piper tuberculatum Jacq fruit. Iran. J. Pharm. Res. 2018, 17, 268-275. [PubMed]

25. Pereira, P.S.; Maia, A.J.; Duarte, A.E.; Oliveira-Tintino, C.D.M.; Tintino, S.R.; Barros, L.M.; Vega-Gomez, M.C.; Rolón, M.; Coronel, C.; Coutinho, H.D.M.; et al. Cytotoxic and anti-kinetoplastid potential of the essential oil of Alpinia speciosa K. Schum. Food Chem. Toxicol. 2018, 119, 387-391. [CrossRef] [PubMed]

26. Pink, R.; Hudson, A.; Mouriès, M.-As.; Bendig, M. Opportunities and challenges in antiparasitic drug discovery. Nat. Rev. Drug Discov. 2005, 4, 727-741. [CrossRef]

27. Zingales, B. Trypanosoma cruzi genetic diversity: Something new for something known about Chagas disease manifestations, serodiagnosis and drug sensitivity. Acta Trop. 2018, 184, 38-52. [CrossRef]

28. Stanaway, J.D.; Roth, G. The burden of Chagas disease. Glob. Heart 2015, 10, 139-144. [CrossRef]

29. Bermudez, J.; Davies, C.; Simonazzi, A.; Pablo, J.; Palma, S. Current drug therapy and pharmaceutical challenges for Chagas disease. Acta Trop. 2016, 156, 1-16. [CrossRef]

30. Rassi, A., Jr.; Rassi, A.; De Rezende, J.M. American trypanosomiasis (Chagas Disease). Infect. Dis. Clin. 2012, 26, 275-291. [CrossRef]

31. Rodríguez-Morales, O.; Monteón-Padilla, V.; Carrillo-Sánchez, S.C.; Rios-Castro, M.; Martínez-Cruz, M.; Carabarin-Lima, A.; Arce-Fonseca, M. Experimental vaccines against Chagas disease: A journey through history. J. Immunol. Res. 2015, 2015, 489758. [CrossRef]

32. Urbina, J.A. Specific chemotherapy of Chagas disease: Relevance, current limitations and new approaches. Acta Trop. 2010, 115, 55-68. [CrossRef]

33. Chatelain, E. Chagas disease drug discovery: Toward a new era. J. Biomol. Screen. 2015, 20, 22-35. [CrossRef] [PubMed]

34. Varela, M.T.; Fernandes, J.P.S. Natural products: Key prototypes to drug discovery against neglected diseases caused by trypanosomatids. Curr. Med. Chem. 2018. [CrossRef]

35. Moreno, É.M.; Leal, S.M.; Stashenko, E.E.; García, L.T. Induction of programmed cell death in Trypanosoma cruzi by Lippia alba essential oils and their major and synergistic terpenes (citral, limonene and caryophyllene oxide). BMC Complement. Altern. Med. 2018, 18, 225. [CrossRef]

36. Estevam, E.B.B.; De Deus, I.P.B.; da Silva, V.P.; Da Silva, E.A.J.; Alves, C.C.F.; Alves, J.M.; Cazal, C.M.; Magalhaes, L.G.; Pagotti, M.C.; Esperandim, V.R.; et al. In vitro antiparasitic activity and chemical composition of the essential oil from Protium ovatum leaves (Burceraceae). An. Acad. Bras. Cienc. 2017, 89, 3005-3013. [CrossRef] [PubMed]

37. Bilia, A.R.; Guccione, C.; Isacchi, B.; Righeschi, C.; Firenzuoli, F.; Bergonzi, M.C. Essential oils loaded in nanosystems: A developing strategy for a successful therapeutic approach. Evidence-Based Complement. Altern. Med. 2014, 2014, 651593. [CrossRef] [PubMed]

38. Hotez, P.J.; Molyneux, D.H.; Fenwick, A.; Kumaresan, J.; Sachs, S.E.; Sachs, J.D.; Savioli, L. Control of neglected tropical diseases. N. Engl. J. Med. 2007, 357, 1018-1027. [CrossRef] [PubMed]

39. Kovats, E. Gas-chromatographische charakterisierung organischer verbindungen. Teil 1: Retentionsindices aliphatischer halogenide, alkohole, aldehyde und ketone. Helv. Chim. Acta 1958, 41, 1915-1932. [CrossRef]

40. Adams, R.P. Identification of Essential Oil Components by Gas Chromatography/Mass Spectrometry; 4th ed.; Allured: Carol Stream, IL, USA, 2007.

41. Satyal, P. Development of GC-MS Database of Essential Oil Components by the Analysis of Natural Essential Oils and Synthetic Compounds and Discovery of Biologically Active Novel Chemotypes in Essential Oils. Ph.D. Thesis, University of Alabama, Huntsville, AL, USA, 2015.

42. Cos, P.; Vlietinck, A.J.; Berghe, D. Vanden; Maes, L. Anti-infective potential of natural products: How to develop a stronger in vitro "proof-of-concept". J. Ethnopharmacol. 2006, 106, 290-302. [CrossRef] 
43. Räz, B.; Iten, M.; Grether-Bühler, Y.; Kaminsky, R.; Brun, R. The Alamar Blue ${ }^{\circledR}$ assay to determine drug sensitivity of African trypanosomes (T. b. rhodesiense and T. b. gambiense) in vitro. Acta Trop. 1997, 68, 139-147. [CrossRef]

44. Trager, W.; Jensen, J.B. Human malaria parasites in continuous culture. J. Parasitol. 2005, 91, 484-486. [CrossRef]

45. Hirumi, H.; Hirumi, K. Continuous cultivation of Trypanosoma brucei blood stream forms in a medium containing a low concentration of serum protein without feeder cell layers. J. Parasitol. 1989, 75, 985-989. [CrossRef] [PubMed]

46. Buckner, F.S.; Verlinde, C.L.M.J.; La Flamme, A.C.; van Voorhis, W.C. Efficient technique for screening drugs for activity against Trypanosoma cruzi using parasites expressing $\beta$-galactosidase. Antimicrob. Agents Chemother. 1996, 40, 2592-2597. [CrossRef] [PubMed]

47. Torres-Santos, E.C.; Moreira, D.L.; Kaplan, M.A.; Meirelles, M.N.; Rossi-Bergmann, B. Selective effect of 2',6'-dihydroxy-4'-methoxychalcone isolated from Piper aduncum on Leishmania amazonensis. Antimicrob. Agents Chemother. 1999, 43, 1234-1241. [CrossRef]

48. Sladowski, D.; Steer, S.J.; Clothier, R.H.; Balls, M. An improved MTT assay. J. Immunol. Methods 1993, 157, 203-207. [CrossRef]

Sample Availability: The essential oil is no longer available from the authors. 